\title{
40. DATA REPORT: UPPER CRETACEOUS AND PALEOGENE CALCAREOUS NANNOFOSSILS FROM THE NORTH PACIFIC ${ }^{1}$
}

\author{
Luc Beaufort ${ }^{2}$ and Gunnar Ólafsson ${ }^{3}$
}

\section{INTRODUCTION}

Few sections have been drilled through the Paleogene and Cretaceous in the northern part of Pacific Ocean. During Deep Sea Drilling Project (DSDP) Leg 19, Site 192 was drilled on the Meiji Guyot, south of the Aleutian Islands. About $100 \mathrm{~m}$ of Paleogene and upper Cretaceous was recovered, but the coring was discontinuous. In particular, no Paleocene material was obtained (Worsley, 1973). Thus, while information is available regarding the late Paleogene history of the Northwest Pacific, the Cretaceous and early Paleogene sedimentary history remains uncertain.

Seven sites were drilled during Ocean Drilling Program (ODP) Leg 145 in the North Pacific during the summer of 1992. The main goal of this "North Pacific Transect" was to improve our understanding of the paleoceanography and paleoclimatology of the North Pacific Ocean and to determine the nature and age of basement. For the latter goal, a particular interest was to date basement on Detroit Seamount, one of the first formed seamounts of the Emperor volcanic chain.

Stratigraphic resolution was achieved through different means for the stratigraphic intervals. Stratigraphic subdivision of the Neogene was achieved through the integration of magnetostratigraphy (Shipboard Scientific Party, 1993; Dubuisson et al., this volume) with diatom (Barron and Gladenkov, this volume; Gladenkov and Barron, this volume) and radiolarian (Morley and Nigrini, this volume; Shilov, this volume) stratigraphy. The calcareous nannofossils, even with their low diversity and abundance in these siliceous sediments, provide some useful stratigraphic information (Ólafsson and Beaufort, this volume).

Sites 883 and 884 are the only sites at which Paleogene calcareous sediments were recovered during Leg 145 (Shipboard Scientific Party, 1993), except for one Oligocene indurated limestone fragment from the basement at Site 887 . Sites 883 and 884 are located on Detroit Seamount. At Site 883, Cretaceous sediments were recovered immediately above basement. The oldest sediment recovered at Site 884 was middle Eocene nannofossil chalk. In these sections calcareous nannofossils provided the critical stratigraphic control. In this data report, the distribution of the calcareous nannofossils in the $\mathrm{Pa}$ leogene and Cretaceous sediments recovered during Leg 145 is given.

\section{METHODS AND PROCEDURES}

Smear slides were prepared for all samples using Ayac (polyvinyl acetate). The calcareous nannofossils were examined in each smear slide by standard light microscopy techniques (plane-polarized light or cross-polarized light) at magnifications ranging from $\times 500$ to

'Rea, D.K., Basov, L.A., Scholl, D.W., and Allan, J.F. (Eds.), 1995. Proc. ODP, Sci. Results, 145: College Station, TX (Ocean Drilling Program).

${ }^{2}$ LGQ-CNRS Luminy, Case 907, 13288 Marseille Cedex 09. France. Current address: LGQ-CNRS, CEREGE BP80, 13545 Aix-en-Provence Cedex 4, France.

${ }^{3}$ Marine Research Institute, P.O. Box 1390. IS-121 Reykjavik, Iceland. $\times 1600$. The abundance of calcareous nannofossil assemblages has been qualitatively estimated as follows:

$$
\begin{aligned}
& A=\text { Abundant: }>10 \text { specimens per field of view }\left(2500 \mu \mathrm{m}^{2}\right. \text { at } \\
& \times 1000) \text {. } \\
& \mathrm{C}=\text { Common: } 1 \text { to } 10 \text { specimens per field of view. } \\
& \mathrm{F}=\text { Few: } 1 \text { specimen per } 1 \text { to } 10 \text { fields of view. } \\
& \mathrm{R}=\text { Rare: only one specimen in more than } 10 \text { fields of view. } \\
& \mathrm{B}=\text { Barren. }
\end{aligned}
$$

Preservation of the calcareous nannofossil assemblages was based on the following criteria:

$\mathrm{G}=$ Good; little or no evidence of dissolution and/or secondary overgrowth of calcite, diagnostic features fully preserved.

$\mathrm{M}=$ Moderate; dissolution and/or secondary overgrowth partially alter primary morphological characteristics, but nearly all specimens can be identified at the species level.

$\mathrm{P}=$ Poor; severe dissolution, fragmentation, and/or secondary calcite overgrowth with primary features largely destroyed; many specimens cannot be identified at the species or generic level.

At the species level, the relative abundance was estimated. The category "abundant" (A) refers to the dominant species ( $>50 \%$ of an assemblage) and "common" (C) refers to the next most abundant taxa (between $10 \%$ and $50 \%$ ). The category designated as "few" (F) constitutes $<10 \%$ of an assemblage, whereas "rare" (R) are taxa for which only one to a few specimens were observed while scanning the slide. On the two tables "cf" means that a taxon is likely to occur but cannot be differentiated from a closely related species because of poor preservation. Discrete taxa regarded as reworked are marked in italic.

\section{SITE LOCATIONS AND MATERIAL}

Site $883\left(51^{\circ} 12^{\prime} \mathrm{N}, 167^{\circ} 46^{\prime} \mathrm{E}\right)$ and Site $884\left(51^{\circ} 27^{\prime} \mathrm{N}, 168^{\circ} 20^{\prime} \mathrm{E}\right)$ were drilled on Detroit Seamount. Site 883 is located in shallower water, at a water depth of $2385 \mathrm{~m}$; Site 884 was drilled in a water depth of $3826 \mathrm{~m}$. Five holes were drilled at this site. About $190 \mathrm{~m}$ of Paleogene and Cretaceous sediment was recovered at Holes 883B and $883 \mathrm{E}$. They consist predominantly of nannofossil chalks and ashy clays above basement.

The specific distribution of the calcareous nannofossil species at Sites 883 and 884 is shown in Tables 1 (back pocket) and 2 .

\section{BIOSTRATIGRAPHY}

\section{Biostratigraphic Scheme}

The biostratigraphic scheme of Martini (1971) is used here for the Paleogene sediments, on the basis that: (1) it is particularly well adapted to mid- and low-latitude sites, and the latitude of Detroit Seamount during the Paleogene should not have exceeded $40^{\circ} \mathrm{N}$ (Clague and Dalrymple, 1989); and that (2) no zonal scheme exists for this re- 
gion. The subdivision of Zones NP14 and NP15 follows Aubry (1991).

\section{Mesozoic Sediments Recovered During Leg 145}

In a few samples just above and in (in fractures filled with calcite) the basalt of Site 883, poorly preserved and low diversified Mesozoic calcareous nannofossil assemblages were found. Only 13 of the 27 samples from Cores 145-883B-87X and 86X yielded coccoliths (Table 1, back pocket). The most abundant species were Micula decussata, $M$. concava, and Watznaueria barneasae. The ranges of most of the species found in these samples are restricted to the Later Cretaceous. In particular, the presence of Ceratolithoides aculeus in the samples implies a Campanian or Maastrichtian age. Sample 145$883 \mathrm{~B}-86 \mathrm{X}-4,90-91 \mathrm{~cm}$, yielded the most diverse and best preserved assemblage of all of the Mesozoic samples observed. In this sample, the few specimens of Lithraphidites of. quadrata that occur suggest a late Maastrichtian age. The curvature angle of $C$. aculeus evolved through the Late Cretaceous (Perch-Nielsen, 1985). At Site 883, its angle is close to $90^{\circ}$ and does not change from sample to sample, which implies that all the Mesozoic samples are of similar age and are possibly early Maastrichtian (Perch-Nielsen, 1985).

The sediment bearing this assemblage consists of ash, which explains the rarity of the nannofossils. The Cretaceous/Paleocene contact lies between Sample 145-883B-85X-CC, where the lowest Cenozoic nannofossils were found, and Sample 145-883B-86X-1, 110$111 \mathrm{~cm}$, where the highest Micula was found.

Some veins inside the pillow lava contain small amounts of calcareous sediment in which we searched for calcareous nannofossils. Sample 145-883E-22R-3, 2-3 cm, contains some Micula sp. and $C$. aculeus.

\section{Paleocene and Eocene Sediments Recovered During Leg 145}

\section{Site 883}

The abundance of calcareous nannofossils is mostly high in the Paleogene sediments. Their preservation is moderate to poor, which limited some specific determinations.

Sample 145-883E-19R-1, 113-114 cm, which yielded Heliolithus kleinpellii, Fasciculithus tympaniformis and Discoaster mohleri in the absence of $H$. riedeli was assigned to Zone NP7.

From Sample 145-883E-19R-1, 75-76 cm, to 145-883E-19R-1, 16-17 cm, specimens of $H$. riedeli, and D. mohleri co-occur without D. multiradiatus. Consequently, this interval was assigned to Zone NP8.

Zone NP9 was identified from Samples 145-883B-85X-4, 120$121 \mathrm{~cm}$, to $145-883 \mathrm{~B}-85 \mathrm{X}-4,4-5 \mathrm{~cm}$. This interval yields both $D$. multiradiatus and $F$. tympaniformis, whereas no Tribrachiatus were observed. The lowest Tribrachiatus observed at this site is T. orthostylus in Sample 145-883B-85X-3, 120-121 cm. Therefore, Zone NP10 is missing at Site 883. The ash layer observed in Sample 145$883 \mathrm{~B}-85 \mathrm{X}-3,140-141 \mathrm{~cm}$, is barren of calcareous nannofossil and marks this inferred hiatus.

The lowest occurrence of Discoaster lodoensis was observed in Sample 145-883B-85X-2, 140-141 cm. Consequently, Zone NP11 was identified from Samples $145-883 B-85 X-3,120-121 \mathrm{~cm}$, to $145-$ 883B-85X-2, 140-141 cm.

The highest occurrence of $T$. orthostylus, which defines the top of Zone NP12, lies between Samples 145-883B-82X-3, 46-47 cm, and $145-883 \mathrm{~B}-82 \mathrm{X}-2,46-47 \mathrm{~cm}$. Zone NP12 is about $30 \mathrm{~m}$ thick. The first occurrence level of $D$. sublodoensis, which defines the base of Zone NP14, was found in Sample 145-883E-14R-CC.

The lowest occurrence of Nannotetrina fulgens, which defines the base of Zone NP15, was found in Section 145-883E-13X-CC. The presence in Section 145-883B-80X-CC of Blackites inflata in the absence of D. kuepperi suggests Zone NP14b.

Several specimens of Chiasmolithus gigas were found in Sample 145-883B-76X-6, 46-47 cm. This sample was therefore assigned to Zone NP15b.

In the absence of $B$. gladius at this site, the lowest occurrence of D. bifax in Sample 145-883B-76X-4, 46-47 cm, was used to delineate Zone NP16. Sample 145-883B-76X-5, $46-47 \mathrm{~cm}$, may belong to Subzone NP15c.

The highest occurrence of $C$. solitus, which defines the top of Zone NP16, is in Sample 145-883B-75X-1, 46-47 cm. The highest occurrences of $D$. saipanensis and $E$. formosa were found also in this sample.

The lowest occurrence of Isthmolithus recurvus in Sample 145883B-74X-CC in the absence of D. saipanensis and E. formosa implied assignment to Zone NP22 for this sample. Therefore, no upper Eocene sediments were recovered at Site 883.

\section{Site 884}

The calcareous nannofossil assemblages are poorly preserved in the Paleogene sediments at Site 884 . The abundance varies but calcareous nannofossils are rarely abundant. Reworking and mixing were commonly observed.

From Samples 145-884B-87X-6, 70-75 cm, to 145-884B-87X-5, $70-75 \mathrm{~cm}$, the calcareous nannofossil assemblages were common, moderately preserved and homogenous. The occurrence of $D$. sublodoensis indicates Zone NP14.

The interval from Samples 145-884B-86X-5, 65-70 cm, to $145-$ $884 \mathrm{~B}-86 \mathrm{X}-4,60-65 \mathrm{~cm}$, yielded few to common poorly preserved nannofossils with low diversity, which resulted from intense dissolution. Because of the absence of marker species, the zonal position is uncertain.

The interval from Samples 145-884B-86X-3, 20-25 cm, to $145-$ $884 \mathrm{~B}-86 \mathrm{X}-1,110-115 \mathrm{~cm}$, yielded abundant to common poorly preserved calcareous nannofossils with a mixed assemblage from Zones NP16, NP15, NP14 and NP13.

In Samples 145-884B-85X-6, 96-101 cm, and 145-884B-85X-5, $124-129 \mathrm{~cm}$, the calcareous nannofossils were common but very poorly preserved with no age diagnostic taxa.

Sample 145-884B-85X-3, 69-74 cm, yielded abundant and moderately preserved calcareous nannofossils. The assemblage shows considerable mixing with $C$. gigas, D. kuepper, D. lodoensis, $R$. hillae and $D$. multiradiatus occurring together.

Samples $145-884 \mathrm{~B}-84 \mathrm{X}-5,100-105 \mathrm{~cm}$, to $145-884 \mathrm{~B}-84 \mathrm{X}-2$, $52-57 \mathrm{~cm}$, yielded highly fragmented coccoliths. Specific determination was uncertain and no zonal assignment was possible.

Samples 145-884B-84X-1, 95-100 cm, to 145-884B-83X-7, 63$70 \mathrm{~cm}$, yielded relatively diverse assemblage, which was also poorly preserved. The presence of $D$. kuepperi indicates reworking in an otherwise undiagnostic middle Eocene (Zone NP15 to NP16) assemblage.

Sample 145-884B-83X-6, 51-56 cm, yielded abundant and poorly preserved calcareous nannofossils, with $C$. solitus and $R$. floridana, which suggest Zone NP16.

Samples $145-884 \mathrm{~B}-83 \mathrm{X}-4,51-56 \mathrm{~cm}$, to $145-884 \mathrm{~B}-83 \mathrm{X}-1,72-$ $77 \mathrm{~cm}$, yielded an abundant and moderately preserved calcareous nannofossil assemblage with few discoasters preserved. Because of the low diversity, poor preservation, uncertain specific determination, and obvious reworking, this interval is difficult to characterize stratigraphically.

In the interval from Samples $145-884 \mathrm{~B}-82 \mathrm{X}-3,107-112 \mathrm{~cm}$, to $145-884 \mathrm{~B}-73 \mathrm{X}-2,103-108 \mathrm{~cm}$, the assemblages are moderately common but poorly preserved. Assemblages characteristic of the early Oligocene Zone NP22 (?NP21) alternate with middle Eocene assemblages and with mixed lower Eocene and lower Oligocene assemblages. 


\section{ACKNOWLEDGMENTS}

We are thankful to M.P. Aubry for her constant encouragement and advice during the course of this work, and to J. Pospichal and I.A. Basov for criticism of an early version of the manuscript, and to $\mathrm{N}$. Buchet for her technical assistance. Funding for this study was provided by INSU/CNRS under IST ("Géosciences Marine") program.

\section{REFERENCES*}

Aubry, M.-P., 1991. Sequence stratigraphy: eustasy or tectonic imprint? J. Geophys. Res., 96:6641-6679.

Clague, D.A., and Dalrymple, G.B., 1989. Tectonics, geochronology, and origin of the Hawaiian-Emperor volcanic chain. In Winterer, E.L., Hussong, D.M., and Decker, R.W. (Eds.), The Eastern Pacific Ocean and Hawaii. Geol. Soc. Am., Geol. of North America Ser., N:188-217.

Martini, E., 1971. Standard Tertiary and Quaternary calcareous nannoplankton zonation. In Farinacci, A. (Ed.), Proc. 2nd Int. Conf. Planktonic Microfossils Roma: Rome (Ed. Tecnosci.), 2:739-785.
Perch-Nielsen, K., 1985. Mesozoic calcareous nannofossils. In Bolli, H.M., Saunders, J.B., and Perch-Nielsen, K. (Eds.), Plankton Stratigraphy: Cambridge (Cambridge Univ. Press), 329-426.

Shipboard Scientific Party, 1993. Site 881. In Rea, D.K., Basov, I.A., Janecek, T.R., Palmer-Julson, A., et al., Proc. ODP, Init. Repts., 145: College Station, TX (Ocean Drilling Program), 37-83.

Worsley, T.R., 1973. Calcareous nannofossils: Leg 19 of the Deep Sea Drilling Project. In Creager, J.S., Scholl, D.W., et al., Init. Repts. DSDP, 19: Washington (U.S. Govt. Printing Office), 741-750.

*Abbreviations for names of organizations and publications in ODP reference lists follow the style given in Chemical Abstracts Service Source Index (published by American Chemical Society).

Date of initial receipt: 13 May 1994 Date of acceptance: 31 August 1994 Ms 145SR-103 
Table 2. Stratigraphic occurrences of calcareous nannofossil species in the Paleogene at Site 884.

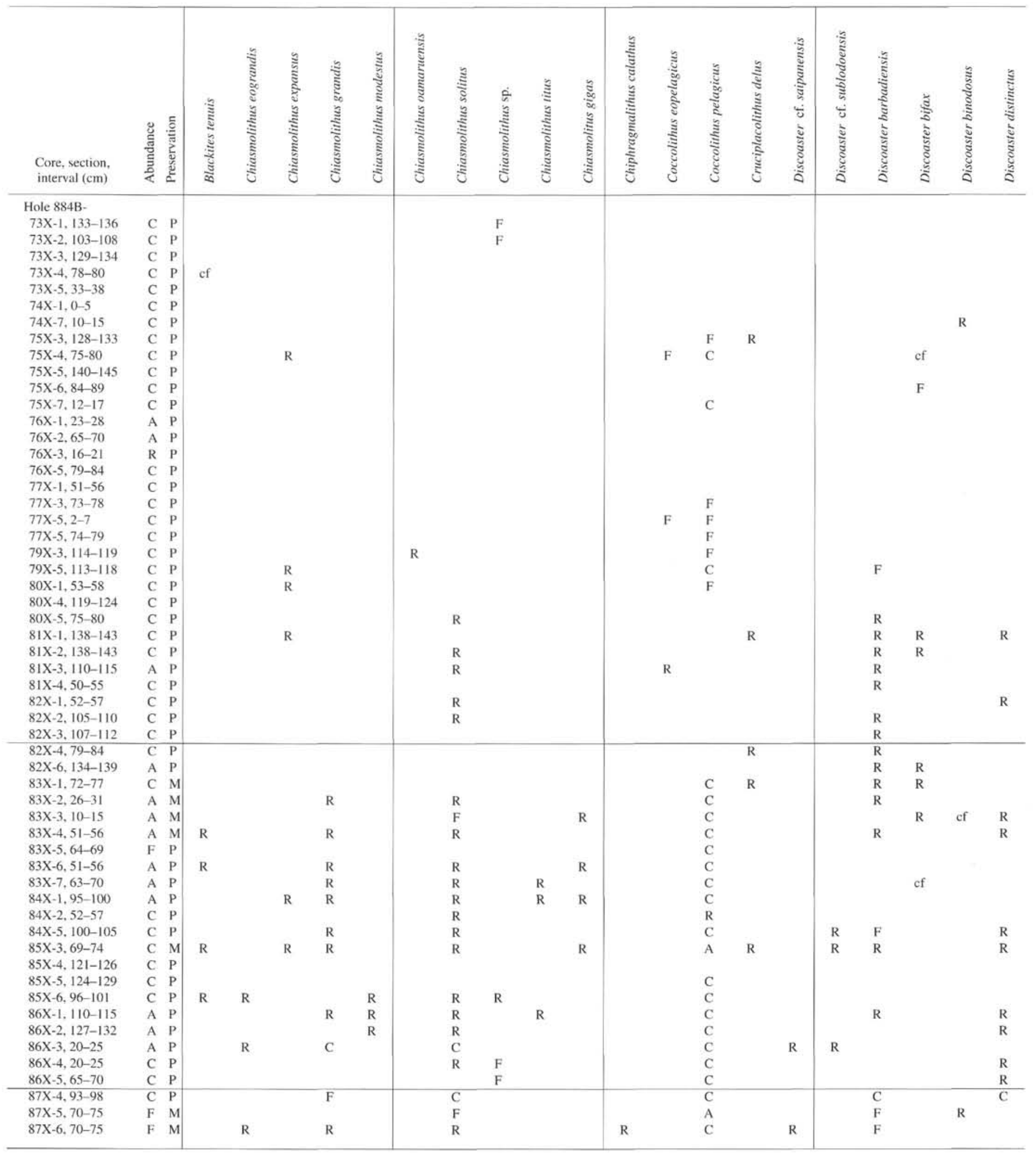


Table 2 (continued).

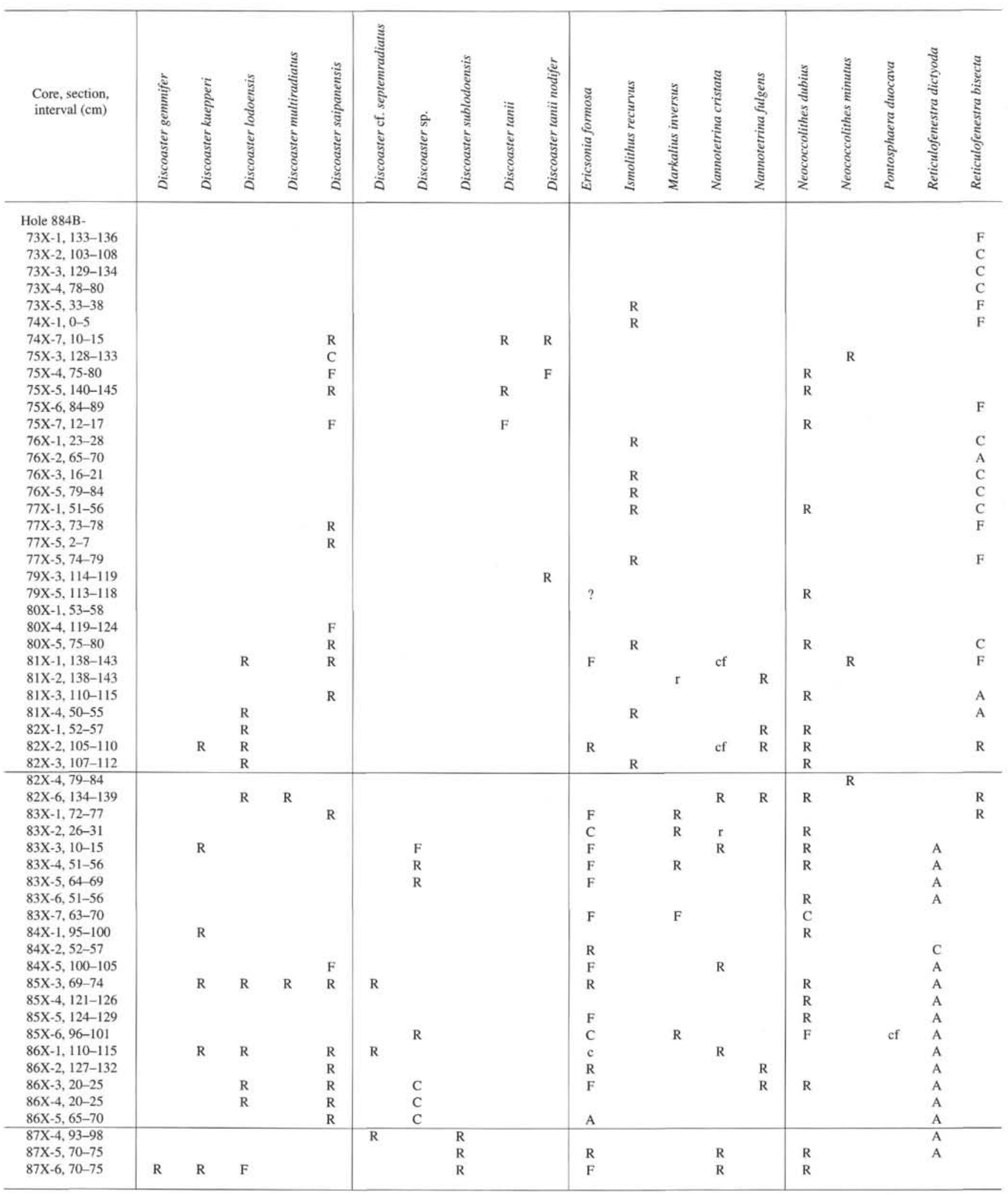


Table 2 (continued).

\begin{tabular}{|c|c|c|c|c|c|c|c|c|c|c|c|c|c|c|c|}
\hline $\begin{array}{l}\text { Core, section, } \\
\text { interval }(\mathrm{cm})\end{array}$ & 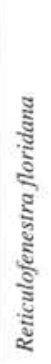 & है & 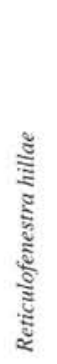 & 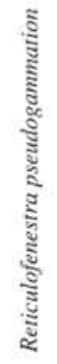 & 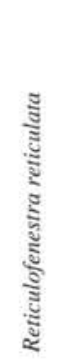 & 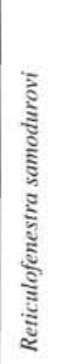 & 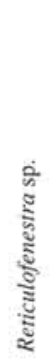 & 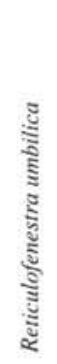 & 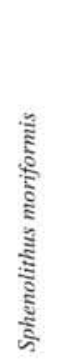 & 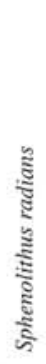 & 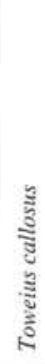 & 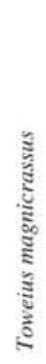 & 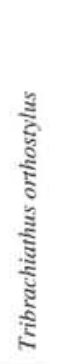 & 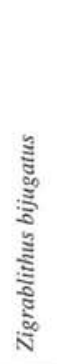 & Zonation \\
\hline $\begin{array}{l}\text { Hole 884B- } \\
73 \mathrm{X}-1,133-136 \\
73 \mathrm{X}-2,103-108 \\
73 \mathrm{X}-3,129-134 \\
73 \mathrm{X}-4,78-80 \\
73 \mathrm{X}-5,33-38 \\
74 \mathrm{X}-1,0-5 \\
74 \mathrm{X}-7,10-15 \\
75 \mathrm{X}-3,128-133 \\
75 \mathrm{X}-4,75-80 \\
75 \mathrm{X}-5,140-145 \\
75 \mathrm{X}-6,84-89 \\
75 \mathrm{X}-7,12-17 \\
76 \mathrm{X}-1,23-28 \\
76 \mathrm{X}-2,65-70 \\
76 \mathrm{X}-3,16-21 \\
76 \mathrm{X}-5,79-84 \\
77 \mathrm{X}-1,51-56 \\
77 \mathrm{X}-3,73-78 \\
77 \mathrm{X}-5,2-7 \\
77 \mathrm{X}-5,74-79 \\
79 \mathrm{X}-3,114-119 \\
79 \mathrm{X}-5,113-118 \\
80 \mathrm{X}-1,53-58 \\
80 \mathrm{X}-4,119-124 \\
80 \mathrm{X}-5,75-80 \\
81 \mathrm{X}-1,138-143 \\
81 X-2,138-143 \\
81 \mathrm{X}-3,110-115 \\
81 \mathrm{X}-4,50-55 \\
82 \mathrm{X}-1,52-57 \\
82 \mathrm{X}-2,105-110 \\
82 \mathrm{X}-3,107-112\end{array}$ & C & C & $\mathrm{R}$ & & & & $\begin{array}{l}\mathrm{A} \\
\mathrm{A}\end{array}$ & $\begin{array}{l}\mathrm{A} \\
\mathrm{C} \\
\mathrm{A} \\
\mathrm{A} \\
\mathrm{A} \\
\mathrm{A} \\
\mathrm{A} \\
\mathrm{A} \\
\mathrm{A} \\
\mathrm{A} \\
\mathrm{A} \\
\mathrm{A} \\
\mathrm{A} \\
\mathrm{A} \\
\mathrm{A} \\
\mathrm{A} \\
\mathrm{A} \\
\mathrm{A} \\
\mathrm{A} \\
\mathrm{A} \\
\mathrm{A} \\
\\
\mathrm{A} \\
\mathrm{A} \\
\mathrm{A} \\
\mathrm{A} \\
\mathrm{A}\end{array}$ & $\mathrm{R}$ & $\mathrm{R}$ & $\mathrm{R}$ & & & & $\begin{array}{l}\text { Mixed } \\
\text { minor } \\
\text { lower } \\
\text { Eocene, } \\
\text { abundant } \\
\text { middle } \\
\text { Eocene, } \\
\text { and } \\
\text { lower } \\
\text { Oligocene } \\
\text { (NP22) }\end{array}$ \\
\hline $\begin{array}{l}82 X-4,79-84 \\
82 X-6,134-139 \\
83 X-1,72-77 \\
83 X-2,26-31 \\
83 X-3,10-15 \\
83 X-4,51-56 \\
83 X-5,64-69 \\
83 X-6,51-56 \\
83 X-7,63-70 \\
84 X-1,95-100 \\
84 X-2,52-57 \\
84 X-5,100-105 \\
85 X-3,69-74 \\
85 X-4,121-126 \\
85 X-5,124-129 \\
85 X-6,96-101 \\
86 X-1,110-115 \\
86 X-2,127-132 \\
86 X-3,20-25 \\
86 X-4,20-25 \\
86 X-5,65-70\end{array}$ & $\begin{array}{l}\mathrm{C} \\
\mathrm{C} \\
\mathrm{C} \\
\mathrm{C} \\
\mathrm{R} \\
\mathrm{F}\end{array}$ & & $\mathrm{R}$ & $\begin{array}{l}\mathrm{R} \\
\mathrm{C} \\
\mathrm{C} \\
\mathrm{C}\end{array}$ & ef & $\begin{array}{l}\mathrm{C} \\
\mathrm{R} \\
\mathrm{R} \\
\mathrm{R}\end{array}$ & $\begin{array}{l}\text { A } \\
\text { A } \\
\\
\text { A } \\
\text { A } \\
\text { A } \\
\text { A } \\
\text { A } \\
\text { A }\end{array}$ & $\begin{array}{l}\mathrm{F} \\
\mathrm{R}\end{array}$ & $\mathrm{R}$ & $\begin{array}{l}\mathrm{R} \\
\mathrm{R}\end{array}$ & & $\mathrm{R}$ & $\mathrm{R}$ & $\mathrm{R}$ & $\begin{array}{l}\text { middle } \\
\text { Eocene } \\
\text { (>=NP16) } \\
\text { with } \\
\text { lower } \\
\text { Eocene } \\
\text { mixed }\end{array}$ \\
\hline $\begin{array}{l}87 X-4,93-98 \\
87 X-5,70-75 \\
87 X-6,70-75\end{array}$ & C & & & $\begin{array}{l}\mathrm{R} \\
\mathrm{R}\end{array}$ & & $\mathrm{R}$ & A & & $\mathrm{R}$ & R & $\mathrm{F}$ & C & $\begin{array}{l}\mathrm{R} \\
\mathrm{R}\end{array}$ & $\begin{array}{l}\mathrm{R} \\
\mathrm{R}\end{array}$ & NP14 \\
\hline
\end{tabular}

